\title{
CEO-CFO Joint Tenure and Earnings Management
}

\begin{abstract}
This study examines the effect of CEO-CFO joint tenure, the length of time a CEO has worked with a CFO at a given firm, on earnings management activities, especially at firms that are more prone to engaging in earnings management to meet or beat an important target, consensus analyst forecasts. We find that prolonged CEO-CFO joint tenure is associated with an increase in both accruals and real earnings management activities among firms that meet or beat analyst expectations by a cent or less. We posit that CEO-CFO joint tenure reflects the formation of trusting relationships between the two executives, which enhance their opportunities to manipulate earnings. Furthermore, we find some evidence that joint tenure explains earnings management among target beating firms more among firms with poorer corporate governance.
\end{abstract}




\section{Introduction}

Despite regulators' and boards' efforts in curbing earnings management over the years, earnings management is still prevalent in firms today. The decision to engage in earnings management appears to be propagated by firms' CEOs and CFOs to accomplish their self-serving objectives. Prior literature documents evidence of earnings management conducted by both the Chief Executive Officers (CEOs) (e.g. Bergstresser and Philippon [2006], Jiang, Petroni, and Wang [2010], Ali and Zhang [2015]) and the Chief Financial Officers (CFOs) [e.g. Beaudoin and Cianci [2015], Jiang, Petroni, and Wang [2010], Feng et al. [2011]] of a firm.

Furthermore, prior literature finds that executives often manage earnings to reach certain thresholds, which include meeting or beating analyst consensus forecasts [Degeorge, Patel, and Zeckhauser [1999], Jiang, Petroni, and Wang [2010], Roychowdhury [2006]]. Only a few studies, however, examine CEOs and CFOs simultaneously, and those that do examine CEO and CFO characteristics separately (for instance, the CEO's equity incentives or pay-performance sensitivity and the CFO's equity incentives or pay-performance sensitivity). In this paper, we examine the impact of a joint CEO-CFO characteristic, the length of the CEO-CFO joint tenure at the firm, on earnings management. We use the joint tenure, defined as the number of years the CEO and CFO have both worked together at their roles at the firm, as a proxy for the development of a trusting working relationship between the two, as Scranati [2001] states, "developing a team mentality requires time and trust." Hence, we posit and find that, given the incentive to meet or beat analysts' consensus forecasts, prolonged CEO and CFO joint tenures are associated with higher accruals and real earnings management activities. 
When engaging in earnings management activities, a couple of aspects need to be considered with respect to the CEOs and CFOs: their incentives and opportunities. Executives' incentives for engaging in earnings management are well documented. Not only is their compensation directly related to their firms' performance and abilities to meet certain thresholds, but so is their longevity in their respective positions (Coughlan and Schmidt [1985], Mergenthaler, Rajgopal, amd Srinivasan [2012]). With respect to opportunity, both CEOs and CFOs are able to manage earnings since they hold top management positions, and U.S. GAAP allows managers to utilize their discretion in many aspects when it comes to accruals. Furthermore, CEOs and CFOs can "call the shots" when it comes to adopting a strategy of engaging in real activities manipulation, such as excessively cutting discretionary spending on investment activities such as R\&D, in order to boost short-term performance measures. Nevertheless, we conjecture that prolonged CEO and CFO joint tenure enhances their opportunities to conduct earnings management activities.

This premise stems from the notion of a "team mentality" and the development of trust amongst executives of a firm. Executives often work together in their decision-making processes. In fact, Hambrick [1995] conducted a survey of CEOs, and they stated that they prefer to collaborate with other top managers within their firm and work as a team. This collaborative effort amongst executives strengthens their relationship and trust amongst one another. The development of a trusting relationship between two executives with clear self-serving incentives to engage in earnings management, CEOs and CFOs, enhances their opportunities to manage earnings through the reduction in the likelihood and costs of detection. CEOs, who are responsible of a firm as a whole, and CFOs, who are in charge of the financial decisions of a firm, can collectively engage in such activities and cover up earnings management to a greater degree. 
On the other hand, although prolonged tenure increases trust amongst executives (Jones and George [1998]), it could also increase executives' loyalties towards the firm. In this scenario, prolonged joint tenure is expected to have no effect on or even decrease earnings management activities, to not sacrifice the firm's long term value. Additionally, Beaudoin and Cianci [2015] show that executives' ethics play a part in their earnings management tendencies. Hence, the greater the number of years CEOs and CFOs work together could increase their ethical standards if one of the executives has high ethical standards, in which case earnings manipulation should decrease.

Another reason why the CEO-CFO joint tenure may not explain earnings management is that CFOs, being subordinates of CEOs, engage in earnings manipulation in response to CEO pressure (Feng et al. [2011]). However, Feng et al. [2011]'s study is conducted in the context of firms receiving Accounting and Auditing Enforcement Releases (AAERs). On the other hand, Jiang, Petroni, and Wang [2010] find that the magnitude of discretionary accruals is more strongly related to CFO equity incentives than to CEO equity incentives.

In addition, there is much anecdotal evidence that suggests executives often work together to manipulate earnings. For instance, the top executives at Enron, Kenneth Lay (CEO) and Andrew Fastow (CFO), created special purpose entities to hide the amount of debt that the organization has been accruing. This resulted in the largest bankruptcy case in US history at the time. This was followed shortly thereafter by the insolvency of WorldCom where the CEO, Bernard Ebbers, and CFO, Scott Sullivan worked together to deliberately and incorrectly capitalize $\$ 3.8$ billion in expenses. Although it has been reported that Sullivan was the one who miscapitalized the expenses, Ebbers was the one who was sentenced to 25 years in prison to Sullivan's 5 years, 
suggesting that both CEO and CFO play significant roles in committing admittedly the most egregious forms of earnings management.

These scandals prompted the initiation of the Sarbanes-Oxley Act of 2002, introducing greater regulatory requirements for US public firms. However, earnings management is still widespread today. Recently, in January of 2018, General Electric reported a $\$ 6.2$ billion insurance loss despite having sold most of its insurance business years ago. It is currently undergoing SEC investigation, but both the CEO and CFO at General Electric, Jeffrey Immelt and Jeffrey Bornstein, respectively, resigned just a few months before General Electric reported the loss.

Due to the prevalence of both accruals and real earnings management (Jiang, Petroni, and Wang [2010], Bergstresser and Philippon [2006], Cohen, Dey, and Lys [2008]), we examine the tendency to engage in both methods of earnings management in this paper. We find that the time period that CEOs and CFOs have worked together at firms that succeeded in meeting or beating consensus analyst forecasts by one cent or less is positively correlated with discretionary accruals and negatively correlated with discretionary expenditures. As a result, we provide evidence that CEO-CFO joint tenure, measured as both the logarithm and tercile rank of the number of years the CEO and CFO worked together at the firm, coupled with the incidence of barely meeting or beating analyst expectations, significantly raises the likelihood of having engaged in accruals and real earnings management.

Furthermore, we find some evidence that CEO-CFO joint tenure matters more in explaining target-beating motivated accrual and real earnings management tactics among firms with low governance (higher entrenchment). In fact, among high governance (low entrenchment) firms, 
joint tenure does not significantly explain earnings management to reach target thresholds. Thus, this highlights the importance of having strong governance mechanisms in place at the firm, or CEOs and CFOs that have worked together long enough to build trust with one another will act on their proclivity to engage in accruals and real earnings management to boost short term performance numbers and compromise the long term value of the firm.

Our paper contributes to the earnings management literature by documenting the effect of CEO and CFO joint tenure at their respective positions at the firm on earnings management. We find that there is a positive effect, but only if the firm barely meets or beats consensus analyst forecasts. Thus, we find that CEOs and CFOs who have worked together for a longer period of time and built up trust with one another are likely to engage in earnings management tactics to be able to meet important targets and not suffer penalties for missing them, such as lower pay, or in extreme cases, dismissal.

We also contribute to the executive characteristics literature by investigating a unique characteristic largely unexplored in prior studies - one that is characterized by not one but both the CEO and CFO - the joint tenure of CEO and CFO at a given firm. CEO tenure on its own has been examined in relation to earnings management (Ali and Zhang [2015]), as well as several CEO and CFO individual characteristics, such as CEO overconfidence (Malmendier, Tate, and Jon [2011]), CEO marital status (Hilary, Huang, and Xu [2017]), and CFO narcissism (Ham et al. [2017]), among many others. However, we examine a characteristic of both CEO and CFO - the joint tenure. It is important to consider such joint characteristics because CEOs and CFOs likely work together, or at the very least are in on it together, in managing the accounting information of the company. 
The rest of the paper is organized as follows. Section II contains prior literature and hypotheses of this paper. Section III consists of the methodology, including regression models and variables. Section IV describes data sources and information on the sample, including sample selection. Section $\mathrm{V}$ reports empirical results, and concluding remarks are presented in section VI.

\section{Prior Literature/Hypotheses}

An extensive literature has uncovered reasons for why CEOs and CFOs manage earnings numbers. Most of these reasons originate from the agency problem, where agents' (CEOs and CFOs) goals are not perfectly aligned with the principals' (shareholders) goals [Eisenhardt [1989], Jensen and Meckling [1976]]. This misalignment is problematic since agents might not always act in the best interest of the principal. It would be advantageous to the shareholders for the firm to produce statements that best display the firm's true economic standing. Not only does that allow current and potential shareholders to assess their options regarding the firm but it would also diminish the chances of having to file a restatement of earnings. As Anderson and Yohn [2002] argue, these restatements provide a negative signal to the public about the credibility of the organizations' financial information. On the other hand, however, CEOs and CFOs might be inclined to inflate or even decrease the companies' earnings for their private benefit for a variety of reasons usually dealing with individual incentives. 
As survey evidence on CFOs by Graham, Harvey, and Rajgopal [2005] indicates, managers view earnings as the most important metric of a firm's performance. For both CEOs and CFOs, their compensation is largely reliant on financial performance measures (Ittner and Larcker [1998], Ittner et al. [2003]). In fact, Healy [1985] argues that CEOs manipulate earnings in an effort to maximize their bonuses and Jiang. Petroni, and Wang [2010] demonstrate that executive equity incentives are strongly associated with a firm's discretionary accruals. Moreover, executives are never ensured of a long tenure at their positions and undoubtedly face career concerns. Coughlan and Schmidt [1985] find that CEO turnover is often preceded by a decrease in stock price, and Barth, Elliot, and Finn [1999] provide evidence of firms displaying continuous earnings growth having higher stock prices than those that do not exhibit such growth patterns. Sul [2019] uses a set of country-level takeover regulations as an exogenous shock to career concerns and finds that managers with greater job security concerns as a result of takeover legislations are more likely to engage in earnings management to inflate accounting information and save their jobs. Other motivations for earnings management include managing relationships with stakeholders (Bowen, Ducharme, and Shores [1995], Burgstahler and Dichev [1997]) and avoiding debt covenant violations (Watts and Zimmerman [1990]).

Furthermore, there are often earnings targets that managers aim to meet or beat in any given fiscal period. Prior literature has demonstrated that managers manipulate earnings to help themselves in meeting or exceeding these target thresholds, which can include consensus analyst forecasts, zero earnings, or prior period earnings (Bergstresser and Philippon [2006], Beaudoin and Cianci [2015], Cohen, Dey, and Lys [2008], Healy [1985], Roychowdhury [2006]). Additionally, Mergenthaler, Rajgopal, amd Srinivasan [2012] find that when a firm misses the analyst 
consensus forecast, CEOs and CFOs receive fewer bonuses and experience greater forced turnover.

The reasons listed above can plausibly lead CEOs and CFOs to engage in earnings management activities to meet or beat targets, increase compensation, decrease the chances of getting fired, or some other self-serving reason. On the other hand, firms, boards, and regulators are continuously working to detect, punish, and prevent earnings management behavior. To align managers' incentives with those of the shareholders', firms often provide stock-based compensation. However, Bergstresser and Philippon [2006] find that accruals earnings management is higher at firms with greater stock-based compensation. Regulators have also required firms to include more independent board members to oversee executives' decisions, and it has been shown to be effective in reducing earnings management, particularly when these independent board members are more financially sophisticated (Xie, Davidson, and DaDalt [2003]). Furthermore, the SEC passed Sarbanes-Oxley Act of 2002 in response to accounting scandals that had arisen during that period, which has successfully resulted in the decline of accrual earnings management activity in recent years. However, real activities management has in turn increased, despite the costliness of this approach to the firm and its shareholders, because of its lower chances of detection, unlike accruals manipulation (Cohen, Dey, and Lys [2008], Graham, Harvey, and Rajgopal [2005]).

Although there are sparse empirical studies that examine CEOs and CFOs simultaneously, there is much anecdotal evidence that suggests executives often work together to manipulate earnings. Moreover, prior studies have demonstrated that CEOs prefer to collaborate with other executives and work as a team in their decision-making processes (Hambrick [1995]), which 
would strengthen their trust of one another in their working relationships and provide them with a greater opportunity to collude in engaging in earnings management activities. We posit that it may be difficult to manage earnings without the assistance, or at least compliance, of the other executive. When CEOs and CFOs collectively engage in earnings management activities, they are essentially acting as a team. However, developing the needed "team mentality" and trust requires time (Jones and George [1998]).

Jiang, Petroni, and Wang [2010] documents that discretionary accruals and beating analyst forecasts are more sensitive to CFO equity incentives than to CEO equity incentives. Meanwhile, as aforementioned in the above literature review, there are many reasons as to why a CEO would want to engage in earnings management beyond equity incentives alone. Thus, it is plausible that the CEO and CFO both collectively manage earnings, each with his or her individual reasons for doing so. However, Feng et al [2011] assert that CFOs succumb to CEOs' pressure to manipulate earnings. They find that CEOs exhibit higher pay-for-performance sensitivity than CFOs, particularly after the reduction of CFOs' incentive based compensation following the passage of the Sarbanes-Oxley Act (Indjejikian and Matejka, [2009]). Hence, CEOs can exert their power to influence or pressure CFOs into manipulating accounting information, and the decision and execution of earnings management is more one-sided (the CEO) than collective (both CEO and CFO). As a result, there is some tension from prior studies regarding whether or not the CEO independently or the CEO and CFO jointly make the decision to engage in earnings management.

Building on these previous studies and aforementioned tension, our main research question is the following: Are CEOs and CFOs who have worked together for a longer period of time more likely to manage earnings in order to meet analysts' forecasts? Based on prior 
literature, there are many reasons to expect both the CEO and CFO to have their respective reasons for wanting to execute earnings management tactics. Thus, we hypothesize that a team consisting of the CEO and CFO, not an individual, manage accounting information, both in the form of accruals manipulation and real activities manipulation, and as Scranati [2001] asserts, "developing a team mentality requires time and trust." Moreover, Jones and George [1998] have shown that sustainable trust within an organization develops over time. Trust between the CEO and CFO is essential in jointly deciding to engage in earnings management, because of the costs of detection involved. However, Feng et al [2011] downplay the role of the CFO, as the CFO gets pressured to follow the CEOs' wishes of earnings management. Furthermore, Beaudoin and Cianci [2015] demonstrate that executives with high ethics standards conduct less accruals management than managers with low ethics. The incoming CEO or CFO might discourage the existing executive from managing earnings to beat targets if the newcomer has high ethical standards. As a result, joint CEO-CFO tenure's role on firms' earnings management behavior is left as an empirical question.

H1a: Longer CEO-CFO joint tenure is associated with an increase in accruals earnings management to meet or beat consensus analyst forecasts.

$\mathrm{H1b}$ : Longer CEO-CFO joint tenure is associated with an increase in real earnings management to meet or beat consensus analyst forecasts. 


\section{Methodology}

We test our hypotheses using an OLS estimation model with earnings management as the dependent variable and CEO-CFO joint tenure as the main independent variable. The model is as follows:

Earnings Management $_{i, t}=\beta 0+\beta 1$ Joint Tenure $_{i, t}+\beta 2$ Meet $_{i, t}+\beta 3{\text { Joint } \text { Tenure }_{i, t}}^{*}$ Meet $_{i, t}+X+Z$ $+Y+\gamma+\delta+\varepsilon$

Earnings management is either accruals or real earnings management utilized in firm $i$ in year $t$ and is described in greater detail below. Joint Tenure $_{i, t}$ is a measure of the number of years in year $t$ for which the CEO and CFO at firm $i$ have worked together. We apply two different variations of this measure: the natural logarithm of one plus the joint tenure in number of years and a yearly tercile ranked joint tenure. This allows for a non-linear relationship between earnings management and joint tenure since CEOs and CFOs likely start managing earnings collectively after a certain point at which they have developed a trusting relationship with one another. $^{1}$

Furthermore, it is more likely that firms will engage in earnings management if they are in close proximity to meeting or beating a target, such as analyst expectations. The literature has shown evidence of analysts pressuring managers to meet short run earnings benchmarks, and

\footnotetext{
${ }^{1}$ We have also conducted the analysis treating joint tenure as a continuous variable in number of years; however, the results were insignificant. This suggests that the relationship is a non-linear one and that, for instance, the likelihood of engaging in earnings management increasing between a CEO-CFO joint tenure of two and three years is not necessarily the same as that increasing between a joint tenure of five and six years. Rather, once the CEO and CFO has worked together long enough to build trust to a point at which the benefits of engaging in earnings management exceed the costs of getting detected, the firm becomes more likely in manipulating numbers.
} 
thus firms with earnings either meeting or closely beating important targets manage earnings more frequently, through both accruals and real earnings management (i.e., Bushee [1998], Bartov, Givoly, and Hayn [2002], Graham, Harvey, and Rajgopal [2005]; Irani and Oesch [2016]). Hence, we include an indicator variable, Meet $_{i, t}$, which equals 1 for observations where a firm meets or just beats the analyst consensus forecast and 0 otherwise. We also include an interaction variable between Meet $_{i, t}$ and Joint Tenure Te $_{i, t}$

As in Cohen, Dey, and Lys [2008] and Roychowdhury [2006], we define Meet $_{i, t}$ as firms that are motivated to engage in income-increasing earnings management with the goal of meeting or barely beating analysts' forecasts by first determining the forecast error for each firmyear observation in our sample. Forecast error is the difference between firm i's actual earnings per share and the analyst consensus forecast in year $t$. Analyst consensus forecast is the average of all analysts' most recent EPS forecast for firm $i$ in year $t$. Firm-year observations with a forecast error between 0 and 1 cent would be considered "suspect" firms with Meet $_{i, t}$ equaling 1.

$X$ is a vector of firm characteristics expected to also affect a firm's earnings management activities, and includes firm size, market to book, litigation risk, leverage, ROA, a loss indicator variable, lagged total accruals and sales growth. $Z$ is a vector of CEO and CFO specific controls, including CEO and CFO age and tenure at their respective positions. This follows prior literature such as Ali and Zhang [2015], who find that earnings management activities varies with CEO tenure at the firm. We also included an internally hired indicator variable to isolate cases where the CEO or CFO was hired within the firm and may have had a relationship with the other executive prior to their appointment. $\mathrm{Y}$ consists of two corporate governance measures, the 
percentage of independent board members and a firm's entrenchment index, E-index (Bebchuk, Cohen, and Farrell [2009]). All variables are defined in detail in appendix A. $\gamma$ and $\delta$ represent industry and year fixed effects, respectively, and are included in all regression models. Firms are grouped into the 12 Fama and French industry classifications. All standard errors from estimations are clustered by firm.

With respect to the coefficients of the main explanatory variable of interest, Joint Tenure $_{i, t} *$ Meet $_{i, t}$, in the model presented as equation 1, if firms with a CEO and CFO who have worked together for a longer tenure and barely meet or beat analyst expectations are more likely to engage in higher levels of earnings management, we would expect $\beta 3$ to be positive if the dependent variable is accruals earnings management and negative if the dependent variable is real earnings management. The details on how each of the earnings management measures was calculated is explained below.

\section{Accruals Earnings Management}

The magnitude of accruals earnings management is calculated based on the modified cross-sectional Jones model (Jones [1991]). The model is estimated for each year and two-digit SIC grouping (industry-year groupings with less than 15 observations are excluded) as follows:

$$
\frac{\text { Total Accruals }_{i, t}}{\text { Assets }_{i, t-1}}=a_{1} \frac{1}{\text { Assets }_{i, t-1}}+a_{2} \frac{\Delta \text { Sales }_{i, t}}{\text { Assets }_{i, t-1}}+a_{2} \frac{P P E_{i, t}}{\text { Assets }_{i, t-1}}+\varepsilon_{i, t}
$$

Where for, firm $i$ and year $t$ : 


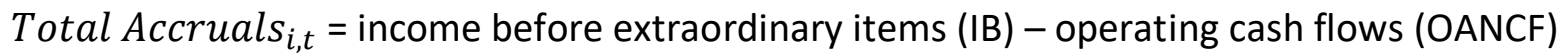
(Hribar and Collins [2002]);

Assets $_{i, t-1}=$ lagged total assets (AT);

$\Delta$ Sales $_{i, t}=$ change in sales (SALE) from the preceding year; and

$P P E_{i, t}=$ Net value of property plant and equipment.

The coefficient estimates from equation 2 are then used in determining the nondiscretionary component of firm i's total accruals in year $t$ as follows:

$$
N D A_{i, t}=a_{1} \frac{1}{\operatorname{Assets}_{i, t-1}}+a_{2} \frac{\Delta \text { Sales }_{i, t}-\Delta \operatorname{Rec}_{i, t}}{\operatorname{Assets}_{i, t-1}}+a_{3} \frac{P P E_{i, t}}{\operatorname{Assets}_{i, t-1}}+\varepsilon_{i, t}
$$

For each firm-year observation, $\Delta \operatorname{Rec}_{i, t}$ is the change in receivables from the preceding year and its inclusion allows for the assumption that all credit sales are discretionary. The difference between total accruals, normalized by lagged total assets, and nondiscretionary accruals is discretionary accruals (DA). In addition, following (Kothari, Leone, and Wasley [2005]), we conducted performance matching by taking the difference in $D A$ between a given firm-year observation and another observation based on the same year, two-digit SIC, and closest ROA to control for the effect of firm performance on discretionary accruals.

\section{Real Earnings Management}

In this paper, we examine a firm's abnormal discretionary expenditures as our measure of real earnings management, following the calculation in Roychowdhury [2006]. Discretionary expenditures include R\&D, advertising and selling, general and administrative expenses. A firm is 
able to report higher earnings if it cuts these discretionary expenses in a given year. The method of deriving abnormal discretionary expenditures is similar to the technique used to calculate abnormal accruals. The regression model is as follows:

$$
\frac{\operatorname{DISEXP}_{i, t}}{\operatorname{Assets}_{i, t-1}}=a_{0}+a_{1} \frac{1}{\text { Assets }_{i, t-1}}+a_{2} \frac{\text { Sales }_{i, t-1}}{\text { Assets }_{i, t-1}}+\varepsilon_{i, t}
$$

The coefficient estimates from equation 4 are then used in determining the "normal" discretionary expenditures of firm $i$ in year $t$. The difference between the actual and "normal" expenditures is the abnormal discretionary expenditures.

\section{Sample and Data}

Our sample period is from 1996-2016 and we extract information from several databases. We begin with all firm-year-executive level data available in Execucomp. ${ }^{2}$ We eliminate all firm-year observations for which either of the CEO and CFO identities is unavailable. ${ }^{3}$ Furthermore, we remove observations for which the executive's start date at the firm is unavailable because it is the main source in determining whether a CEO or CFO is internally hired (hired while the CEO or

\footnotetext{
2 Using Execucomp limits our sample of firms to those that are or have been in the S\&P 1500.

${ }^{3}$ We identify CEOs following Execucomp's classification (CEOANN=CEO). However, when identifying CFOs, in addition to following the Execucomp terminology (CFOANN=CFO), we also manually searched annual titles including variations of "chief finance" and "CFO" because of numerous missing fields associated with CFOANN.
} 
CFO was already working for the same company). These sample screens leave us with 6,190 firmyear observations with sufficient CEO and CFO information.

In addition, we obtain analyst consensus forecasts from IBES. ${ }^{4}$ We use the analyst consensus forecast to compute the just meet or beat variable (Meet) for each firm-year observation. Firmspecific financial information, including those necessary in computing discretionary accruals and discretionary expenses, is gathered from Compustat. Moreover, we incorporate some corporate governance measures from the ISS database in order to control for CEO entrenchment and board independence. After merging all datasets and excluding observations with missing data, we end up with 2,164 firm-year observations to run our least restrictive test, the discretionary accruals model. All continuous variables are winsorized at the $1 \%$ and $99 \%$ levels and all standard errors are clustered at the firm level. Industry and year fixed effects are included in all models. Details pertaining to the sample construction can be found in Table 1.

Table 2 provides the descriptive statistics. A few numbers are worth mentioning. The mean and median firm in our sample is profitable, with only around $17 \%$ of firm-years being a loss year. The mean and median firm experiences positive sales growth from the previous year, and has a market to book of around 2.2 (median) to 2.9 (mean). The mean and median firm has negative signed discretionary accruals (less accruals management), and also negative abnormal discretionary expenditures (greater real earnings management). About $31 \%$ of observations are in high litigation industries. The median CFO tenure is 4 years, and the median CEO tenure is 7 years, with the median CEO-CFO joint tenure of 4 years. The means are all slightly larger than the

\footnotetext{
${ }^{4}$ The consensus forecast is calculated by taking all of the last individual analyst forecasts for a firm and for a given year from the IBES Detail files and taking the average.
} 
median tenures. About $49 \%$ of CEOs and CFOs were hired from within the same firm they had been working for. Finally, about $10.1 \%$ of firm-years meet or beat analyst consensus forecasts by a cent or less.

\section{Results}

\section{Accruals Earnings Management}

Table 3, Panels A and B present the results from the discretionary accruals regressions. Panel A displays the results using the natural logarithm of the number of years of CEO-CFO joint tenure, whereas Panel B, joint tenure is expressed as a tercile rank. In Columns 1 and 2 of both Panel A and Panel $B$, the coefficient on joint tenure is not significant. This suggests that on average, the length of time the CEO and CFO has worked together is not significantly correlated with the use of accruals earnings management.

In Columns 3 and 4, however, we include the Meet variable and an interaction term between Meet and Joint Tenure. We find that the coefficient on this interaction term is positive and significant in both Columns 3 and 4 and in both Panels A and B. Economically speaking, for the median firm that meets or beats analyst expectations by at most a cent, a one-year increase in CEO-CFO joint tenure corresponds to an increase of discretionary accruals of roughly $32.5 \%$ from the sample median value of discretionary accruals.

Many of the control variables in both panels of Table 3 are consistent with prior literature. Firms with higher performance, as measured by ROA, are associated with higher accruals earnings management, consistent with Kothari, Leone, and Wasley [2005]. On the other hand, 
larger firms conduct less earnings management activities, consistent with Watts and Zimmerman [1986]. Moreover, firms with higher leverage engage in greater accruals earnings management, which is in line with firms managing earnings to avoid violating debt covenants (latridis and Kadorinis [2009], Defond and Jiambalvo [1994]).

Thus, Table 3 provides initial evidence that longer CEO-CFO joint tenure increases the likelihood that these managers engage in accruals-based earnings management in order to meet or beat the analysts' consensus forecast, which is consistent with our initial hypothesis.

\section{Real Earnings Management}

Table 4 reports the results of the abnormal discretionary expenditures regression model. Similarly with Table 3, Table 4 presents results in two panels: Panel A presents results using the logged measure of CEO-CFO joint tenure, and Panel B presents results using the tercile rank of joint tenure.

In Columns 1 and 2 in both Panels A and B of Table 4, similar to accruals management, we find that real earnings management is on average not significantly correlated with CEO-CFO joint tenure. Once we include the meet or beat indicator and the interaction between Meet and Joint Tenure, however, we find that the coefficient on the interaction term is negative and significant in three out of four specifications presented in Columns 3 and 4 in both Panels. The only insignificant result is in Column 3 of Panel $B$, but this is when no control variables are included in the estimation. Nonetheless, the overall negative and significant result on the double interaction implies that firms that barely meet or beat analyst expectations are incrementally more likely to 
engage in real earnings management activities (spend abnormally less on discretionary expenditures).

Interestingly, we find that the main effect of Meet is significant and positive. This suggests that if the CEO and CFO had no prior history of working together at the firm as CEO and CFO (the joint tenure is zero years), then meeting or beating the analyst consensus is significantly negatively correlated with real earnings management. Thus, the tendency to engage in real earnings management, which can boost short-term earnings performance but also undoubtedly be detrimental to long-term shareholder value (Irani and Oesch [2015]), in order to meet or beat targets, may only be a plausible option when the CEO and CFO have a longer working relationship and are on the same page with respect to manipulating investment activities despite a potential loss of long-term value. Hence, for the median firm that meets or beats analyst expectations in our sample, an increase of one year in joint tenure corresponds to an incremental $7 \%$ increase in real earnings management (or decrease in abnormal discretionary expenditures).

The control variables in all panels of Table 4 are consistent with prior literature. The significantly negative coefficient on size is consistent with smaller firms spending more on R\&D and advertising (Mansfield [1981]). The positive coefficient on sales growth supports the concept that growth firms spend more on R\&D and advertising (Roychowdhury [2006]). The negative coefficient on the leverage ratio is in line with the notion that financially distressed firms spend less on discretionary expenditures (Kini and Williams [2012]).

Thus, Table 4 provides further evidence that longer CEO-CFO joint tenure increases the likelihood that these managers engage in earnings management in order to meet or beat the analysts' consensus forecast, this time in the form of real activities manipulation, specifically the 
cutting of discretionary expenditures. Although the result is weaker than for accruals earnings management, we are able to find consistent results implying that among firms that meet or beat analyst targets, a longer CEO-CFO joint tenure makes it more feasible to engage in both accruals and real earnings management.

\section{Role of Governance}

In Tables 5 and 6, we split the sample into two based on the sample median of our measure of governance - the entrenchment index (or E-index). The group of observations with above-median E-index values make up the low governance group, while the rest make up the low governance group. We then run the discretionary accruals model (Table 5) and the discretionary expenses model (Table 6) for each subsample. Our interest in seeing the difference in the coefficients of the Meet ${ }^{*}$ Joint Tenure interaction term between the two subsamples. Our expectation is that firms with strong governance (less entrenchment) are less likely to resort to earnings management activities than firms with weak governance even with longer CEO-CFO tenure.

In Table 5, Panels A and B, we find that the coefficient on Meet * Joint Tenure is only positive and significant for the low governance subsample, whereas the coefficient is insignificant in the strong governance subsample..$^{5}$ In Panel $A$, the low governance coefficient on the interaction term (0.041) is nearly twice that of the high governance coefficient (0.021). In Panel $B$, the weak governance group coefficient $(0.045)$ is 2.5 times that of the strong governance group coefficient (0.018). Thus, these results are consistent with governance serving as a mitigating

\footnotetext{
${ }^{5}$ Control variables are included in all cross-sectional tests but are untabulated for parsimony.
} 
factor in longer jointly tenured CEOs and CFOs resorting to accruals management to meet or beat expectations. As a caveat, however, neither chi-squared test statistic of differences between the two subsamples in Table 5 are significant, but power may be an issue given the relatively small number of observations in our subsample analyses.

In Table 6, we find a similar pattern for real earnings management. Only the low governance (high entrenchment) subsample has a significant correlation between abnormal discretionary expenditures and the interaction between meet-or-beat indicator and CEO-CFO joint tenure. However, although Panel B shows that the interaction coefficient for the low governance group $(-0.038)$ is twice the magnitude of the coefficient for the high governance group (-0.019), the chi-squared test statistics of differences in the coefficients are essentially zero in both Panels $A$ and $B$.

Thus, although we lack power and significance in the chi-squared test statistics, we find moderate evidence of CEO-CFO joint tenure helping firms meet or beat analyst targets by engaging in accruals and real earnings management primarily in firms that also lack strong governance structures and are characterized by high levels of entrenchment.

Internal vs. External CEO/CFO Hires

Tables 7 and 8 depict results of our accruals and real earnings management tests from Tables 3 and 4, Column 4, for subsamples separating CEOs and CFOs who were hired internally from the same firm and CEOs and CFOs who were hired to their current positions from the outside - from a different firm. This cross-sectional test is interesting because joint tenure may matter more in engaging in earnings management activities for external hires because there is a greater 
likelihood that the CEO and CFO do not know one another and have to work together for a longer period of time to foster a trusting working relationship. On the other hand, joint tenure may not matter as much for internal hires because the new hire may already have a trusting working relationship with the existing CEO or CFO because the new hire had already been at the firm, albeit in a different position.

Surprisingly, results in Table 7, Panels A and B, provide evidence that joint tenure and target beating is significantly correlated with discretionary accruals for the internal CEO hires and insignificant for the external CEO hires. The magnitude of the coefficients across the two subsamples show that the internal CEO hire subsample coefficient ( 0.038 and 0.034$)$ is more than four times greater than that of the external CEO hire subsample (0.008). However, neither chisquared test statistic of differences across subsamples is significant. Perhaps it does not matter how long an externally hired CEO works with a CFO to foster a trusting enough relationship to engage in earnings manipulation for the objective of target beating, while for internally hired CEOs it is easier to build such a relationship to longer the CEO has worked with the CFO.

Table 8, Panels A and B, contains results for discretionary expenditures across the internally and externally hired CEO subsamples. In these estimations, we find that the interaction coefficient is insignificant in both subsamples and differences in coefficients are statistically insignificant.

Panels $C$ and $D$ in Tables 7 and 8 provide results for subsample splits based on internally versus externally hired CFOs. We find weak evidence that the target-beating and joint tenure interaction explains earnings management more for externally hired CFOs than for internally hired CFOs. Hence, across Tables 7 and 8 we fail to find consistent results regarding internally 
versus externally hired executives and the impact of joint tenure on earnings management. We find some evidence that joint tenure matters more in explaining earnings management for internally hired CEOs than for externally hired CFOs.

\section{Conclusion}

Prior studies have demonstrated that both CEOs and CFOs engage in earnings management activities (Healy [1985], Bergstresser and Philippon [2006], Beaudoin and Cianci [2015], Jiang, Petroni, and Wang [2010], Graham, Harvey, and Rajgopal [2005], Ali and Zhang [2015]) and that it is often motivated by reaching certain earnings thresholds. This study is different in that it examines the effect of CEO-CFO joint tenure on earnings management activities conducted to meet one of the earnings targets, analysts' consensus forecast. We predict that longer joint tenure is associated with an increase in such activities since it allows CEOs and CFOs to develop a trusting relationship, which would enhance their opportunity to collectively manage earnings by decreasing the associated detection costs. We indeed find that, within our sample, longer CEO-CFO joint tenure is associated with an increase in accruals and real earnings management activities when a firm just meets or beats analyst consensus forecast. We also provide some evidence that high governance hinders this relationship, which highlights the importance of strong governance practices within an organization. 


\section{References}

ALI, A., AND W. ZHANG "CEO Tenure and Earnings Management." Journal of Accounting and Economics 59 (2015): 60-79.

ANDERSON, K., AND T. YOHN "The Effect of 10k Restatements on Firm Value, Information, Asymmetries, and Investors' Reliance on Earnings." Working paper, Georgetown University and Indiana University, 2002. Available at https://papers.ssrn.com/sol3/papers.cfm?abstract_id=332380.

BARTH, M.; J. ELLIOT; AND M. FINN “Market Rewards Associated with Patterns of Increasing Earnings." Journal of Accounting Research 37 (1999): 387-413.

BARTOV, E.; D. GIVOLY; AND C. HAYN “The Rewards to Meeting or Beating Earnings Expectations" Journal of Accounting and Economics 33 (2002): 173-204.

BEAUDOIN, C., AND A. CIANCI "The Impact of CFOs' Incentives and Earnings Management Ethics on their Financial Reporting Decisions: The Mediating Role of Moral Disengagement." Journal of Business Ethics 128 (2015): 505-518.

BEBCHUK, L.; A. COHEN; AND A. FERRELL "What Matters in Corporate Governance?" The Review of Financial Studies 22 (2009): 783-827.

BERGSTRESSER, D., AND T. PHILIPPON “CEO Incentives and Earnings Management." Journal of Financial Economics 80 (2006): 511-529.

BOWEN, R.; L. DUCHARME; AND D.SHORES "Stakeholders' Implicit Claims and Accounting Method Choice." Journal of Accounting and Economics 20 (1995): 255-295.

BURGSTAHLER, D., AND I. DICHEV “Earnings Management to Avoid Earnings Decreases and Losses." Journal of Accounting and Economics 24 (1997): 99-126.

BUSHEE, B. "Institutional Investors, Long-Term Investment, and Earnings Management." Unpublished doctoral dissertation, University of Pennsylvania, 1998. Available at https://papers.ssrn. com/sol3 /papers.cfm?abstract_id=52686

COHEN, D.; A. DEY; AND T. LYS "Real and Accrual-Based Earnings Management in the Pre- and PostSarbanes-Oxley Periods." The Accounting Review 83 (2008): 757-787.

COUGHLAN, A., AND R. SCHMIDT "Executive Compensation, Management Turnover, and Firm Performance: An Empirical Investigation." Journal of Accounting and Economics 7 (1985): 43-66.

DEFOND, M., AND J. JIAMBALVO “Debt Covenant Violation and Manipulation of Accruals." Journal of Accounting and Economics 17 (1994): 145-176.

DEGEORGE, F.; J. PATEL; AND R. ZECKHAUSER "Earnings Management to Exceed Thresholds." The Journal of Business 72 (1999): 1-33. 
EISENHARDT, K. "Agency Theory: An Assessment and Review" The Academy of Management Review 14 (1989): 57-73.

FENG, M.; W. GE; S. LUO; AND T. SHEVLIN “Why do CFOs Become Involved in Material Accounting Manipulations?" Journal of Accounting and Economics 51 (2011): 21-36.

GRAHAM, J.; C. HARVEY; AND S. RAJGOPAL "The Economic Implications of Corporate Financial Reporting." Journal of Accounting and Economics 40 (2005): 3-73.

HAM, C.; M. LANG; N. SEYBERT; AND S. WANG “CFO Narcissism and Financial Reporting Quality." Journal of Accounting Research 55 (2017): 1089-1135.

HAMBRICK, D. "Fragmentation and the Other Problems CEOs have with their Top Management Teams." California Management Review 37 (1995): 110-127.

HEALY, P. "The Effect of Bonus Schemes on Accounting Decisions." Journal of Accounting and Economics 7 (1985): 85-107.

HILARY, G.; S. HUANG; AND Y. XU “Marital Status and Earnings Management." European Accounting Review 26 (2017): 153-158.

HRIBAR, P., AND D. COLLINS “Errors in Estimating Accruals: Implications for Empirical Research." Journal of Accounting Research 40 (2002): 105-134.

IATRIDIS, G., AND G. KADORINIS “Earnings Management and Firm Financial Motives: A Financial Investigation of UK Listed Firms." International Review of Financial Analysis 18 (2009): 164-173.

INDJEJIKIAN, R., AND M. MATEJKA “CFO Fiduciary Responsibilities and Annual Bonus Incentives." Journal of Accounting Research 47 (2009): 1061-1093.

IRANI, R., AND O. DAVID “Analyst Coverage and Real Earnings Management: Quasi-Experimental Evidence." Journal of Financial and Quantitative Analysis 51 (2016): 589-627.

ITTNER, C., AND D. LARCKER "Innovations in Performance Measurement: Trends and Research Implications." Journal of Management Accounting Research 10 (1998): 205-238.

ITTNER, C.; D. LARCKER; AND M. MEYER "Subjectivity and the Weighting of Performance Measures: Evidence from a Balanced Scorecard." The Accounting Review 78 (2003): 725-758.

JENSEN, M., AND W. MECKLING "Theory of the Firm: Managerial Behavior, Agency Cost and Ownership Structure." Journal of Financial Economics 3 (1976): 305-360.

JIANG, J.; K. PETRONI; AND I. WANG "CFOs and CEOs: Who Have the Most Influence on Earnings Management." Journal of Financial Economics 96 (2010): 513-526.

JONES, G., AND J. GEORGE "The Experience and Evolution of Trust: Implications for Cooperation and Teamwork." Academy of Management Review 23 (1998): 531-546.

JONES, J. "Earnings Management During Import Relief Investigations." Journal of Accounting Research 29 (1991): 193-228. 
KINI, O., AND R. WILLIAMS “Tournament Incentives, Firm Risk, and Corporate Policies." Journal of Financial Economics 103 (2012): 350-376.

KOTHARI, S.; A. LEONE; AND C. WASLEY "Performance Matched Discretionary Accrual Measures." Journal of Accounting and Economics 39 (2005): 163-197.

MALMENDIER , U.; G. TATE; AND Y. JON “Overconfidence and Early-Life Experiences: The Effect of Managerial Traits on Corporate Financial Policies.” Journal of Finance 66 (2011): 1687-1733.

MANSFIELD, E. "Composition of R and D Expenditures: Relationship to Size of Firm, Concentration, and Innovative Output." The Review of Economics and Statistics 63 (1981): 610-615.

MERGENTHALER, R.; S. RAJGOPAL; AND S. SRINIVASAN “CEO and CFO Penalties to Missing Quarterly Analysts Forecasts." Working paper, The University of Arizona, Columbia Business School, and Harvard Business School, 2012. Available at https://papers.ssrn.com/sol3/papers.cfm?abstract_id=1152421.

ROYCHOWDHURY, S. "Earnings Management Through Real Activities Manipulation." Journal of Accounting and Economics 42 (2006): 335-370.

SCRANATI, J. "On Becoming a Team Player." Team Performance Management: An International Journal 7 (2001): 5-10.

SUL, E. "Takeover Threats, Job Security Concerns, and Earnings Management." Working paper, George Washington University, 2019. Available at https://papers.ssrn.com/sol3/papers.cfm?abstract_id= 3034948

WATTS, R., AND J. ZIMMERMAN “Positive Accounting Theory.” Prentice-Hall Inc., New Jersey, USA (1986)

WATTS, R., AND J. ZIMMERMAN “Positive Accounting Theory - A 10 Year Perspective." The Accounting Review 65 (1990): 131-156.

XIE, B.; W. DAVIDSON; AND P. DADALT "Earnings Management and Corporate Governance: the Role of the Board and Audit Committee." Journal of Corporate Finance, 9 (2003): 295-316. 


\section{Appendix:}

\begin{tabular}{|c|c|}
\hline Discretionary Accruals $(D A)_{i, t}$ & $\begin{array}{l}\text { firm i's abnormal accruals in year t, computed } \\
\text { following the modified jones model (Jones [1991]) and } \\
\text { performance matched. }\end{array}$ \\
\hline Discretionary expenditures $_{i, t}$ & $\begin{array}{l}R \& D \text { expenses }+ \text { Advertising expenses }+S G \& A \\
\text { expenses. If } R \& D \text { expenses or Advertising expenses are } \\
\text { missing, they are set equal to } 0 .\end{array}$ \\
\hline $\begin{array}{l}\text { Abnormal } \\
\text { discretionary expenditures }_{i, t}\end{array}$ & $\begin{array}{l}\text { actual discretionary expenses of firm i in yeart - } \\
\text { "normal" discretionary expenses as in Roychowdhury } \\
\text { (2006). }\end{array}$ \\
\hline Meet $_{i, t}$ & $\begin{array}{l}\text { indicator variable equal to } 1 \text { if firm i's forecast error is } \\
\text { within } 1 \text { cent in year t; } 0 \text { otherwise. }\end{array}$ \\
\hline Joint Tenure , $_{i, t}$ & $\begin{array}{l}\text { number of years firm i's CEO and CFO have worked } \\
\text { together in yeart, as in execucomp. It is either treated } \\
\text { as the natural logarithm of the number of years } \\
\text { worked together plus one or as a rank variable. }\end{array}$ \\
\hline Market Capitalization $_{i, t}$ & $\begin{array}{l}\text { number of outstanding common shares (CSHO) X } \\
\text { annual, fiscal closing price (PRCC_F). }\end{array}$ \\
\hline Size $_{i, t}$ & natural logarithm of market capitalization. \\
\hline Market to Book ${ }_{i, t}$ & $\begin{array}{l}\text { market capitalization / book value of common equity } \\
\text { (CEQ). }\end{array}$ \\
\hline Litigation Risk $_{i, t}$ & $\begin{array}{l}\text { indicator variable equal to } 1 \text { if SIC code is 2833-2836, } \\
3570-3577,3600-3674,5200-5961,7370-7374 ; 0 \\
\text { otherwise [Ali and Zhang (2015)]. }\end{array}$ \\
\hline Leverage $_{i, t}$ & total debt $(D L C+D L T T) /$ total assets $(A T)$ \\
\hline$R O A_{i, t}$ & $\begin{array}{l}\text { earnings before extraordinary items (IB) / total assets } \\
\text { at the beginning of the year (lagged } A T) \text {. }\end{array}$ \\
\hline
\end{tabular}




\begin{tabular}{|c|c|}
\hline $\operatorname{LosS}_{i, t}$ & $\begin{array}{l}\text { indicator variable equal to } 1 \text { if firm i reports a net loss } \\
\text { in year } t ; 0 \text { otherwise. }\end{array}$ \\
\hline Lagged Total Accruals ${ }_{i, t}$ & $\begin{array}{l}\text { firm i's total accruals scaled by its beginning total } \\
\text { assets in year } t-1 \text {. }\end{array}$ \\
\hline Sales Growth ${ }_{i, t}$ & $\begin{array}{l}\text { change in firm i's sales from the preceding year divided } \\
\text { by the preceding year's sales. }\end{array}$ \\
\hline CEO age $_{i, t}$ & CEO age in firm i at year $t$, as found in Execucomp. \\
\hline${\text { CFO } \text { age }_{i, t}}$ & CFO age in firm i at year $t$, as found in Execucomp. \\
\hline Internally hired $_{i, t}$ & $\begin{array}{l}\text { indicator variable equal to } 1 \text { if both CEO and CFO are } \\
\text { internal hires in firm i at year t; } 0 \text { otherwise. }\end{array}$ \\
\hline CEO tenure $e_{i, t}$ & $\begin{array}{l}\text { the number of years the CEO has been in his/her } \\
\text { position, in firm i at yeart, as found in Execucomp. }\end{array}$ \\
\hline CFO tenure tent & $\begin{array}{l}\text { the number of years the CFO has been in his/her } \\
\text { position, in firm i at year } t \text {, as found in Execucomp. }\end{array}$ \\
\hline Board independence $_{i, t}$ & $\begin{array}{l}\text { percentage of independent board members in firm i at } \\
\text { year } t \text {, as found on the ISS database. }\end{array}$ \\
\hline$E-$ index $x_{i, t}$ & $\begin{array}{l}\text { the entrenchment index introduced by Bebchuk, } \\
\text { Cohen, and Ferrell [2009]. }\end{array}$ \\
\hline
\end{tabular}


Table 1: Sample Construction

\begin{tabular}{|c|c|}
\hline & Observations \\
\hline $\begin{array}{l}\text { Execucomp - firm-year observations with data available for CEO and CFO join } \\
\text { dates }\end{array}$ & 6,190 \\
\hline $\begin{array}{l}\text { Merging the Execucomp database with the Compustat, IBES, and ISS } \\
\text { databases- firm-year observations after merging with Compustat and deleting } \\
\text { observations with negative asset values and those from the financial sector. }\end{array}$ & $\underline{5,493}$ \\
\hline $\begin{array}{l}\text { Remove observations with missing variable values from the Execucomp } \\
\text { database - the reduction in sample size is mainly due to missing executive age }\end{array}$ & 4,508 \\
\hline $\begin{array}{l}\text { Remove observations with missing variable values from the Compustat } \\
\text { database }\end{array}$ & 4,273 \\
\hline Remove observations with missing variable values from the IBES database - & 4,214 \\
\hline $\begin{array}{l}\text { Remove observations with missing variable values from the ISS databases } \\
\text { (Final Sample) - the reduction in sample size is due to missing values for both } \\
\text { the E-index and Board Independence. }\end{array}$ & 2,164 \\
\hline
\end{tabular}


Table 2: Descriptive Statistics

\begin{tabular}{lcccccc}
\hline VARIABLES & $\mathrm{N}$ & mean & $\mathrm{sd}$ & $\mathrm{p} 25$ & $\mathrm{p} 50$ & $\mathrm{p} 75$ \\
\hline Size & 2,215 & 7.455 & 1.521 & 6.445 & 7.325 & 8.390 \\
ROA & 2,215 & 0.0526 & 0.107 & 0.0224 & 0.0597 & 0.103 \\
Sales Growth & 2,215 & 0.0927 & 0.217 & -0.0077 & 0.0803 & 0.172 \\
Litigation & 2,215 & 0.307 & 0.461 & 0 & 0 & 1 \\
Leverage & 2,215 & 0.188 & 0.177 & 0.0091 & 0.164 & 0.299 \\
Disc Accruals & 2,164 & -0.0239 & 0.163 & -0.0923 & -0.0157 & 0.0542 \\
Abs Disc Accruals & 2,164 & 0.116 & 0.126 & 0.0319 & 0.0751 & 0.155 \\
MTB & 2,215 & 2.937 & 3.124 & 1.480 & 2.221 & 3.535 \\
Loss & 2,215 & 0.172 & 0.377 & 0 & 0 & 0 \\
Lagged Total Accruals & 2,215 & -0.0689 & 0.0845 & -0.104 & -0.0600 & -0.0272 \\
Abn Disc Expenditures & 2,069 & -0.137 & 0.249 & -0.288 & -0.110 & 0.0146 \\
CFO Tenure & 2,215 & 5.200 & 3.703 & 2 & 4 & 7 \\
CEO Tenure & 2,215 & 10.06 & 9.085 & 4 & 7 & 13 \\
Joint Tenure & 2,215 & 4.300 & 3.109 & 2 & 4 & 6 \\
Internally Hired & 2,215 & 0.486 & 0.500 & 0 & 0 & 1 \\
CFO age & 2,215 & 51.28 & 6.550 & 47 & 51 & 56 \\
CEO Agge & 2,215 & 55.58 & 7.353 & 50 & 55 & 60 \\
Analyst Following & 2,215 & 14.86 & 10.34 & 7 & 12 & 21 \\
Meet & 2,215 & 0.101 & 0.302 & 0 & 0 & 0 \\
E-index & 2,215 & 2.814 & 1.344 & 2 & 3 & 4 \\
Board Independence & 2,215 & 0.711 & 0.156 & 0.625 & 0.727 & 0.857
\end{tabular}

Table 1 provides summary statistics for variables used in the earnings management analyses. Variables are defined as follows: Disc accruals is firm i's abnormal accruals in year t, computed following the Jones (1991) model modified by matching on performance; Abn Disc Expenditures is firm i's R\&D expenses, Advertising expenses, and SG\&A expenses in year $\mathrm{t}$; Size is the natural logarithm of market capitalization; $R O A$ is earnings before extraordinary items (IB) / total assets at the beginning of the year (AT_1); Sales Growth is the change in firm i's sales from the preceding year divided by the preceding year's sales; Litigation is an indicator variable equal to 1 if the industry SIC code falls between 2833-2836, 3570-3577, 3600-3674, 5200-5961, 7370-7374, and 0 otherwise; Leverage is total debt (DLC + DLTT) / total assets (AT); Market to Book is market capitalization / book value of common equity (CEQ); Loss is an indicator variable equal to 1 if firm i reports a net loss in year $\mathrm{t}, 0$ otherwise; Lagged total accruals is firm i's total accruals scaled by their beginning total assets (AT_1); CFO (CEO) tenure is the number of years the CFO (CEO) has been in his/her position, in firm i at year $\mathrm{t}$; Joint tenure is number of years firm i's CEO and CFO have worked together in year t; Internally Hired is an indicator variable equal to 1 if both CEO and CFO are internal hires in firm i at year t, 0 otherwise; CFO (CEO) age is CFO (CEO) age in firm i at year $\mathrm{t}$; Meet is an indicator variable equal to 1 if firm i's forecast error is within 1 cent in year t, 0 otherwise; $E$-index is the entrenchment index introduced by Bebchuk, Cohen, and Ferrell (2009); Board Independence is the percentage of independent board members in firm i at year $t$, from the ISS database. All financial data is from Compustat and all executive data is from Execucomp. 
Table 3: The Effect of Joint Tenure on Accruals Earnings Management

Panel A: Dependent Variable = Discretionary Accruals; Joint tenure - log

\begin{tabular}{|c|c|c|c|c|}
\hline VARIABLES & 1 & 2 & 3 & 4 \\
\hline Meet & & & $\begin{array}{c}-0.030 \\
(-1.597)\end{array}$ & $\begin{array}{c}-0.027 \\
(-1.399)\end{array}$ \\
\hline Joint Tenure (log) & $\begin{array}{c}-0.002 \\
(-0.308)\end{array}$ & $\begin{array}{c}-0.002 \\
(-0.317)\end{array}$ & $\begin{array}{c}-0.004 \\
(-0.772)\end{array}$ & $\begin{array}{c}-0.005 \\
(-0.699)\end{array}$ \\
\hline Meet $*$ Joint Tenure $(\log )$ & & & $\begin{array}{l}0.029 * \\
(1.910)\end{array}$ & $\begin{array}{l}0.028^{*} \\
(1.802)\end{array}$ \\
\hline ROA & & $\begin{array}{c}0.329 * * * \\
(4.059)\end{array}$ & & $\begin{array}{c}0.331 \text { *** } \\
(4.094)\end{array}$ \\
\hline Loss & & $\begin{array}{c}0.012 \\
(0.704)\end{array}$ & & $\begin{array}{c}0.012 \\
(0.740)\end{array}$ \\
\hline Size & & $\begin{array}{c}-0.009 * * \\
(-2.563)\end{array}$ & & $\begin{array}{c}-0.008 * * \\
(-2.510)\end{array}$ \\
\hline MTB & & $\begin{array}{l}-0.003^{*} \\
(-1.958)\end{array}$ & & $\begin{array}{c}-0.003^{* *} \\
(-2.002)\end{array}$ \\
\hline Leverage & & $\begin{array}{c}0.074 * * * \\
(2.678)\end{array}$ & & $\begin{array}{c}0.074 * * * \\
(2.663)\end{array}$ \\
\hline Litigation & & $\begin{array}{c}-0.006 \\
(-0.507)\end{array}$ & & $\begin{array}{c}-0.007 \\
(-0.563)\end{array}$ \\
\hline Sales Growth & & $\begin{array}{c}-0.002 \\
(-0.091)\end{array}$ & & $\begin{array}{c}-0.002 \\
(-0.097)\end{array}$ \\
\hline Lagged Total Accruals & & $\begin{array}{c}-0.034 \\
(-0.728)\end{array}$ & & $\begin{array}{c}-0.035 \\
(-0.748)\end{array}$ \\
\hline Internally Hired & & $\begin{array}{c}-0.014 \\
(-1.634)\end{array}$ & & $\begin{array}{c}-0.014 \\
(-1.565)\end{array}$ \\
\hline CEO age & & $\begin{array}{c}-0.000 \\
(-0.148)\end{array}$ & & $\begin{array}{c}-0.000 \\
(-0.228)\end{array}$ \\
\hline CFO age & & $\begin{array}{c}0.000 \\
(0.706)\end{array}$ & & $\begin{array}{c}0.000 \\
(0.622)\end{array}$ \\
\hline CEO tenure & & $\begin{array}{c}-0.000 \\
(-0.436)\end{array}$ & & $\begin{array}{c}-0.000 \\
(-0.367)\end{array}$ \\
\hline CFO tenure & & $\begin{array}{c}0.001 \\
(0.384)\end{array}$ & & $\begin{array}{c}0.001 \\
(0.473)\end{array}$ \\
\hline Board Independence & & $\begin{array}{l}-0.050^{*} \\
(-1.734)\end{array}$ & & $\begin{array}{l}-0.048^{*} \\
(-1.657)\end{array}$ \\
\hline E-index & & $\begin{array}{c}0.001 \\
(0.308)\end{array}$ & & $\begin{array}{c}0.001 \\
(0.354)\end{array}$ \\
\hline Constant & $\begin{array}{l}-0.045^{*} \\
(-1.691)\end{array}$ & $\begin{array}{c}-0.010 \\
(-0.179)\end{array}$ & $\begin{array}{c}-0.039 \\
(-1.461)\end{array}$ & $\begin{array}{c}-0.003 \\
(-0.057)\end{array}$ \\
\hline Observations & 2,164 & 2,164 & 2,164 & 2,164 \\
\hline Industry FE & YES & YES & YES & YES \\
\hline Year FE & YES & YES & YES & YES \\
\hline Adjusted R-squared & 0.0135 & 0.0404 & 0.0148 & 0.0419 \\
\hline
\end{tabular}

$* * * \mathrm{p}<0.01, * * \mathrm{p}<0.05, * \mathrm{p}<0.1$ 
Panel B: Dependent Variable = Discretionary Accruals; Joint tenure - rank (terciles)

\begin{tabular}{|c|c|c|c|c|}
\hline VARIABLES & 1 & 2 & 3 & 4 \\
\hline Meet & & & $\begin{array}{c}-0.024 \\
(-1.604)\end{array}$ & $\begin{array}{c}-0.021 \\
(-1.361)\end{array}$ \\
\hline Joint tenure (rank) & $\begin{array}{c}-0.001 \\
(-0.119)\end{array}$ & $\begin{array}{c}-0.001 \\
(-0.088)\end{array}$ & $\begin{array}{c}-0.003 \\
(-0.658)\end{array}$ & $\begin{array}{c}-0.003 \\
(-0.552)\end{array}$ \\
\hline Meet $*$ Joint tenure (rank) & & & $\begin{array}{c}0.028 * * \\
(2.442)\end{array}$ & $\begin{array}{c}0.026^{* *} \\
(2.237)\end{array}$ \\
\hline ROA & & $\begin{array}{c}0.329 * * * \\
(4.058)\end{array}$ & & $\begin{array}{c}0.331 * * * \\
(4.089)\end{array}$ \\
\hline Loss & & $\begin{array}{c}0.012 \\
(0.705)\end{array}$ & & $\begin{array}{c}0.012 \\
(0.729)\end{array}$ \\
\hline Size & & $\begin{array}{c}-0.008 * * \\
(-2.561)\end{array}$ & & $\begin{array}{c}-0.008 * * \\
(-2.502)\end{array}$ \\
\hline Market to Book & & $\begin{array}{c}-0.003 * * \\
(-1.961)\end{array}$ & & $\begin{array}{c}-0.003 * * \\
(-1.979)\end{array}$ \\
\hline Leverage & & $\begin{array}{c}0.074 * * * \\
(2.680)\end{array}$ & & $\begin{array}{c}0.074 * * * \\
(2.647)\end{array}$ \\
\hline Litigation & & $\begin{array}{c}-0.006 \\
(-0.511)\end{array}$ & & $\begin{array}{c}-0.007 \\
(-0.578)\end{array}$ \\
\hline Sales growth & & $\begin{array}{c}-0.003 \\
(-0.102)\end{array}$ & & $\begin{array}{c}-0.003 \\
(-0.123)\end{array}$ \\
\hline Lagged total accruals & & $\begin{array}{c}-0.035 \\
(-0.742)\end{array}$ & & $\begin{array}{c}-0.035 \\
(-0.754)\end{array}$ \\
\hline Internally hired & & $\begin{array}{l}-0.015^{*} \\
(-1.649)\end{array}$ & & $\begin{array}{c}-0.014 \\
(-1.579)\end{array}$ \\
\hline CEO age & & $\begin{array}{c}-0.000 \\
(-0.151)\end{array}$ & & $\begin{array}{c}-0.000 \\
(-0.242)\end{array}$ \\
\hline CFO age & & $\begin{array}{c}0.000 \\
(0.710)\end{array}$ & & $\begin{array}{c}0.000 \\
(0.643)\end{array}$ \\
\hline CEO tenure & & $\begin{array}{c}-0.000 \\
(-0.518)\end{array}$ & & $\begin{array}{c}-0.000 \\
(-0.446)\end{array}$ \\
\hline CFO tenure & & $\begin{array}{c}0.000 \\
(0.265)\end{array}$ & & $\begin{array}{c}0.000 \\
(0.327)\end{array}$ \\
\hline Board Independence & & $\begin{array}{l}-0.051^{*} \\
(-1.763)\end{array}$ & & $\begin{array}{l}-0.049 * \\
(-1.679)\end{array}$ \\
\hline E-index & & $\begin{array}{c}0.001 \\
(0.300)\end{array}$ & & $\begin{array}{c}0.001 \\
(0.342)\end{array}$ \\
\hline Constant & $\begin{array}{c}-0.046 * \\
(-1.746)\end{array}$ & $\begin{array}{c}-0.010 \\
(-0.181)\end{array}$ & $\begin{array}{c}-0.041 \\
(-1.524)\end{array}$ & $\begin{array}{c}-0.004 \\
(-0.069)\end{array}$ \\
\hline Observations & 2,164 & 2,164 & 2,164 & 2,164 \\
\hline Industry FE & YES & YES & YES & YES \\
\hline Year FE & YES & YES & YES & YES \\
\hline Adjusted R-squared & 0.0134 & 0.0405 & 0.0148 & 0.0421 \\
\hline
\end{tabular}

Table 3 presents OLS estimations of accruals earnings management on CEO-CFO joint tenure. Panel A reports the natural logarithm of joint tenure, while panel B joint tenure is ranked into terciles. Industry and Year fixed effects are included in all columns. Standard errors are clustered by firm. T-statistics are found in the parenthesis. ${ }^{*}, * *$, and $* * *$ represent two-tailed significance at $10 \%, 5 \%$, and $1 \%$, respectively. 
Table 4: The Effect of Joint Tenure on Real Earnings Management

Panel A: Dependent Variable: Abnormal Discretionary Expenses; Joint tenure-log

\begin{tabular}{|c|c|c|c|c|}
\hline VARIABLES & 1 & 2 & 3 & 4 \\
\hline Meet & & & $\begin{array}{c}0.050 * * \\
(2.083)\end{array}$ & $\begin{array}{c}0.042 * * \\
(2.117)\end{array}$ \\
\hline Joint Tenure $(\log )$ & $\begin{array}{c}0.005 \\
(0.598)\end{array}$ & $\begin{array}{c}-0.006 \\
(-0.464)\end{array}$ & $\begin{array}{c}0.009 \\
(0.930)\end{array}$ & $\begin{array}{c}-0.002 \\
(-0.182)\end{array}$ \\
\hline Meet $*$ Joint Tenure $(\log )$ & & & $\begin{array}{l}-0.031^{*} \\
(-1.775)\end{array}$ & $\begin{array}{c}-0.031^{* *} \\
(-1.997)\end{array}$ \\
\hline ROA & & $\begin{array}{c}-0.053 \\
(-0.551)\end{array}$ & & $\begin{array}{c}-0.055 \\
(-0.570)\end{array}$ \\
\hline Loss & & $\begin{array}{c}0.013 \\
(0.797)\end{array}$ & & $\begin{array}{c}0.012 \\
(0.776)\end{array}$ \\
\hline Size & & $\begin{array}{c}-0.016^{* *} \\
(-2.352)\end{array}$ & & $\begin{array}{c}-0.017 * * \\
(-2.403)\end{array}$ \\
\hline MTB & & $\begin{array}{c}0.003 \\
(1.367)\end{array}$ & & $\begin{array}{c}0.003 \\
(1.402)\end{array}$ \\
\hline Leverage & & $\begin{array}{c}-0.162 * * * \\
(-3.277)\end{array}$ & & $\begin{array}{c}-0.159 * * * \\
(-3.223)\end{array}$ \\
\hline Litigation & & $\begin{array}{c}0.055^{*} \\
(1.744)\end{array}$ & & $\begin{array}{l}0.055^{*} \\
(1.787)\end{array}$ \\
\hline Sales Growth & & $\begin{array}{c}0.164 * * * \\
(9.228)\end{array}$ & & $\begin{array}{c}0.163^{* * *} * \\
(9.350)\end{array}$ \\
\hline Lagged Total Accruals & & $\begin{array}{l}-0.094^{*} \\
(-1.890)\end{array}$ & & $\begin{array}{l}-0.095^{*} \\
(-1.892)\end{array}$ \\
\hline Internally Hired & & $\begin{array}{c}0.003 \\
(0.176)\end{array}$ & & $\begin{array}{c}0.004 \\
(0.193)\end{array}$ \\
\hline CEO age & & $\begin{array}{l}0.002^{*} \\
(1.803)\end{array}$ & & $\begin{array}{l}0.002 * \\
(1.853)\end{array}$ \\
\hline $\mathrm{CFO}$ age & & $\begin{array}{c}-0.002 \\
(-1.080)\end{array}$ & & $\begin{array}{c}-0.002 \\
(-1.073)\end{array}$ \\
\hline CEO tenure & & $\begin{array}{c}0.000 \\
(0.086)\end{array}$ & & $\begin{array}{c}0.000 \\
(0.087)\end{array}$ \\
\hline CFO tenure & & $\begin{array}{c}0.003 \\
(1.217)\end{array}$ & & $\begin{array}{c}0.003 \\
(1.111)\end{array}$ \\
\hline Board Independence & & $\begin{array}{c}-0.002 \\
(-0.043)\end{array}$ & & $\begin{array}{c}-0.003 \\
(-0.068)\end{array}$ \\
\hline E-index & & $\begin{array}{c}-0.002 \\
(-0.377)\end{array}$ & & $\begin{array}{c}-0.002 \\
(-0.411)\end{array}$ \\
\hline Constant & $\begin{array}{c}0.091 \\
(1.533)\end{array}$ & $\begin{array}{c}0.168 \\
(1.599)\end{array}$ & $\begin{array}{c}0.082 \\
(1.461)\end{array}$ & $\begin{array}{c}0.157 \\
(1.505)\end{array}$ \\
\hline Observations & 2,069 & 2,069 & 2,069 & 2,069 \\
\hline Industry FE & YES & YES & YES & YES \\
\hline Year FE & YES & YES & YES & YES \\
\hline Adjusted R-squared & 0.146 & 0.206 & 0.148 & 0.206 \\
\hline
\end{tabular}


Panel B: Dependent Variable: Abnormal Discretionary Expenses; Joint tenure-rank (terciles)

\begin{tabular}{|c|c|c|c|c|}
\hline VARIABLES & 3 & 4 & 5 & 6 \\
\hline Meet & & & $\begin{array}{c}0.039 * * \\
(1.963)\end{array}$ & $\begin{array}{l}0.030 * \\
(1.857)\end{array}$ \\
\hline Joint Tenure (rank) & $\begin{array}{c}0.002 \\
(0.218)\end{array}$ & $\begin{array}{c}-0.007 \\
(-0.696)\end{array}$ & $\begin{array}{c}0.004 \\
(0.566)\end{array}$ & $\begin{array}{c}-0.004 \\
(-0.404)\end{array}$ \\
\hline Meet $*$ Joint Tenure (rank) & & & $\begin{array}{c}-0.025 \\
(-1.589)\end{array}$ & $\begin{array}{l}-0.024^{*} \\
(-1.727)\end{array}$ \\
\hline ROA & & $\begin{array}{c}-0.053 \\
(-0.550)\end{array}$ & & $\begin{array}{c}-0.054 \\
(-0.560)\end{array}$ \\
\hline Loss & & $\begin{array}{c}0.013 \\
(0.789)\end{array}$ & & $\begin{array}{c}0.013 \\
(0.783)\end{array}$ \\
\hline Size & & $\begin{array}{c}-0.017 * * \\
(-2.360)\end{array}$ & & $\begin{array}{c}-0.017 * * \\
(-2.399)\end{array}$ \\
\hline MTB & & $\begin{array}{c}0.003 \\
(1.359)\end{array}$ & & $\begin{array}{c}0.003 \\
(1.376)\end{array}$ \\
\hline Leverage & & $\begin{array}{c}-0.162 * * * \\
(-3.288)\end{array}$ & & $\begin{array}{c}-0.160 * * * \\
(-3.242)\end{array}$ \\
\hline Litigation & & $\begin{array}{l}0.055^{*} \\
(1.752)\end{array}$ & & $\begin{array}{l}0.056^{*} \\
(1.794)\end{array}$ \\
\hline Sales Growth & & $\begin{array}{c}0.164 * * * \\
(9.267)\end{array}$ & & $\begin{array}{c}0.163 * * * \\
(9.313)\end{array}$ \\
\hline Lagged Total Accruals & & $\begin{array}{l}-0.094^{*} \\
(-1.873)\end{array}$ & & $\begin{array}{l}-0.095^{*} \\
(-1.897)\end{array}$ \\
\hline Internally Hired & & $\begin{array}{c}0.004 \\
(0.182)\end{array}$ & & $\begin{array}{c}0.004 \\
(0.195)\end{array}$ \\
\hline CEO age & & $\begin{array}{l}0.002^{*} \\
(1.799)\end{array}$ & & $\begin{array}{l}0.002 * \\
(1.852)\end{array}$ \\
\hline CFO age & & $\begin{array}{c}-0.002 \\
(-1.078)\end{array}$ & & $\begin{array}{c}-0.002 \\
(-1.072)\end{array}$ \\
\hline CEO tenure & & $\begin{array}{c}0.000 \\
(0.125)\end{array}$ & & $\begin{array}{c}0.000 \\
(0.129)\end{array}$ \\
\hline CFO tenure & & $\begin{array}{c}0.003 \\
(1.355)\end{array}$ & & $\begin{array}{c}0.003 \\
(1.284)\end{array}$ \\
\hline Board Independence & & $\begin{array}{c}-0.002 \\
(-0.038)\end{array}$ & & $\begin{array}{c}-0.003 \\
(-0.065)\end{array}$ \\
\hline E-index & & $\begin{array}{c}-0.002 \\
(-0.384)\end{array}$ & & $\begin{array}{c}-0.002 \\
(-0.411)\end{array}$ \\
\hline Constant & $\begin{array}{c}0.093 \\
(1.585)\end{array}$ & $\begin{array}{c}0.166 \\
(1.569)\end{array}$ & $\begin{array}{c}0.086 \\
(1.533)\end{array}$ & $\begin{array}{c}0.157 \\
(1.499)\end{array}$ \\
\hline Observations & 2,069 & 2,069 & 2,069 & 2,069 \\
\hline Industry FE & YES & YES & YES & YES \\
\hline Year FE & YES & YES & YES & YES \\
\hline Adjusted R-squared & 0.146 & 0.206 & 0.147 & 0.206 \\
\hline
\end{tabular}

Table 4 presents OLS estimations of abnormal discretionary expenditures on CEO-CFO joint tenure. Panel A reports the natural logarithm of joint tenure, while panel B joint tenure is ranked into terciles. Industry and Year fixed effects are included in all columns. Standard errors are clustered by firm. T-statistics are found in the parenthesis. *, **, and *** represent two-tailed significance at $10 \%, 5 \%$, and $1 \%$, respectively. 
Table 5: The Effect of Joint Tenure on Accruals Earnings Management, Governance Splits Panel A: Dependent Variable: Discretionary Accruals; Joint tenure-log

\begin{tabular}{lcc}
\hline VARIABLES & Low Governance & High Governan \\
\hline & & \\
Meet & -0.017 & -0.030 \\
Joint Tenure (log) & $(-0.605)$ & $(-1.212)$ \\
& -0.014 & -0.003 \\
Meet * Joint Tenure (log) & $(-0.922)$ & $(-0.403)$ \\
& $0.041^{*}$ & 0.021 \\
Observations & $(1.855)$ & $(1.123)$ \\
Controls & 693 & 1,471 \\
Industry FE & YES & YES \\
Year FE & YES & YES \\
Adjusted R-squared & YES & YES \\
& 0.0721 & 0.0535
\end{tabular}

Ha: $\beta 3$ (low governance) $\neq \beta 3$ (high governance)

$\chi^{2}=0.49$

Panel B: Dependent Variable: Discretionary Accruals; Joint tenure-rank

\begin{tabular}{lcc}
\hline VARIABLES & Low Governance & High Governance \\
\hline \multirow{2}{*}{ Meet } & -0.013 & \\
& $(-0.559)$ & -0.023 \\
Joint Tenure (rank) & 0.002 & $-1.188)$ \\
& $(0.140)$ & -0.006 \\
Meet * Joint Tenure (rank) & $0.045^{* * *}$ & $-0.823)$ \\
& $(2.724)$ & 0.018 \\
Observations & 693 & $(1.246)$ \\
Controls & YES & 1,471 \\
Industry FE & YES & YES \\
Year FE & YES & YES \\
Adjusted R-squared & 0.0717 & YES \\
& & 0.0537 \\
\hline
\end{tabular}

Ha: $\beta 3$ (low governance) $\neq \beta 3$ (high governance)

$\chi^{2}=1.76$

Table 5 presents OLS estimations of accruals earnings management on CEO-CFO joint tenure, split into two subsamples. One subsample consists of firms with low governance based on the yearly median E-Index measure, while the other subsample consists of firms with high governance based on the yearly median E-index measure. Panel A reports the natural logarithm of joint tenure, while panel B joint tenure is ranked into terciles. Industry and Year fixed effects are included in all columns. Standard errors are clustered by firm. T-statistics are found in the parenthesis. *, **, and *** represent two-tailed significance at $10 \%, 5 \%$, and $1 \%$, respectively. Chi-squared test statistics of differences in the coefficients of Meet*Joint Tenure across the two subsamples are also presented. 
Table 6: The Effect of Joint Tenure on Real Earnings Management, Governance Splits Panel A: Dependent Variable: Abnormal Discretionary Expenses; Joint tenure-log

\begin{tabular}{lcc}
\hline VARIABLES & Low Governance & High Governance \\
\hline \multirow{2}{*}{ Meet } & 0.048 & \\
& $(1.570)$ & 0.041 \\
Joint Tenure $(\log )$ & -0.001 & -0.000 \\
& $(-0.038)$ & $(-0.013)$ \\
Meet * Joint Tenure $(\log )$ & $-0.043^{*}$ & -0.029 \\
& $(-1.771)$ & $(-1.564)$ \\
Observations & 665 & 1,404 \\
Controls & YES & YES \\
Industry FE & YES & YES \\
Year FE & YES & YES \\
Adjusted R-squared & 0.260 & 0.186 \\
\end{tabular}

Ha: $\beta 3$ (low governance) $\neq \beta 3$ (high governance)

$\chi^{2}=0.00$

Panel B: Dependent Variable: Abnormal Discretionary Expenses; Joint tenure-rank

\begin{tabular}{lcc}
\hline VARIABLES & Low Governance & High Governance \\
\hline \multirow{2}{*}{ Meet } & 0.036 & \\
& $(1.513)$ & 0.027 \\
Joint Tenure (rank) & -0.006 & -0.003 \\
& $(-0.479)$ & $(-0.244)$ \\
Meet* Joint Tenure (rank) & $-0.038^{*}$ & -0.019 \\
& $(-1.783)$ & $(-1.161)$ \\
Observations & 665 & 1,404 \\
Controls & YES & YES \\
Industry FE & YES & YES \\
Year FE & YES & YES \\
Adjusted R-squared & 0.261 & 0.186 \\
& & \\
\hline
\end{tabular}

Ha: $\beta 3$ (low governance) $\neq \beta 3$ (high governance)

$\chi^{2}=0.00$

Table 6 presents OLS estimations of abnormal discretionary expenses on CEO-CFO joint tenure, split into two subsamples. One subsample consists of firms with low governance based on the yearly median E-Index measure, while the other subsample consists of firms with high governance based on the yearly median E-index measure. Panel A reports the natural logarithm of joint tenure, while panel B joint tenure is ranked into terciles. Industry and Year fixed effects are included in all columns. Standard errors are clustered by firm. T-statistics are found in the parenthesis. *, **, and *** represent two-tailed significance at $10 \%, 5 \%$, and $1 \%$, respectively. Chi-squared test statistics of differences in the coefficients of Meet*Joint Tenure across the two subsamples are also presented. 
Table 7: The Effect of Joint Tenure on Accruals Earnings Management, Internal vs. External CEO/CFO hires

Panel A: Dependent Variable: Discretionary Accruals; Joint tenure-log; Hire - CEO

\begin{tabular}{lcc}
\hline VARIABLES & CEO Internal & CEO External \\
\hline Meet & $-0.045^{* *}$ & \\
& $(-1.979)$ & 0.014 \\
Joint Tenure $(\log )$ & -0.006 & $0.401)$ \\
& $(-0.723)$ & $(0.289)$ \\
Meet * Joint Tenure $(\log )$ & $0.038^{* *}$ & 0.008 \\
& $(1.971)$ & $(0.331)$ \\
Observations & 1,417 & 747 \\
Number of firms & 291 & 178 \\
Industry FE & YES & YES \\
Year FE & YES & YES \\
Adjusted R-squared & 0.0226 & 0.114 \\
\end{tabular}

Ha: $\beta 3$ (CEO Internal) $\neq \beta 3$ (CEO External)

$\chi^{2}=1.24$

Panel B: Dependent Variable: Discretionary Accruals; Joint tenure-rank; Hire - CEO

\begin{tabular}{lcc}
\hline VARIABLES & CEO Internal & CEO External \\
\hline & & \\
Meet & $-0.035^{*}$ & 0.016 \\
& $(-1.948)$ & $(0.585)$ \\
Joint Tenure (rank) & -0.003 & 0.000 \\
& $(-0.375)$ & $(0.012)$ \\
Meet * Joint Tenure (rank) & $0.034^{* *}$ & 0.008 \\
& $(2.379)$ & $(0.367)$ \\
Observations & 1,417 & 747 \\
Number of firms & 291 & 178 \\
Industry FE & YES & YES \\
Year FE & YES & YES \\
Adjusted R-squared & 0.0231 & 0.113 \\
\end{tabular}

Ha: $\beta 3$ (CEO Internal) $\neq \beta 3$ (CEO External)

$\chi^{2}=1.18$ 
Panel C: Dependent Variable: Discretionary Accruals; Joint tenure-log; Hire - CFO

\begin{tabular}{lcc}
\hline VARIABLES & CFO Internal & CFO External \\
\hline \multirow{2}{*}{ Meet } & -0.023 & $-0.045^{*}$ \\
& $(-0.793)$ & $(-1.822)$ \\
Joint Tenure $(\log )$ & -0.014 & 0.007 \\
& $(-1.326)$ & $(0.615)$ \\
Meet * Joint Tenure $(\log )$ & $0.037^{*}$ & $0.036^{*}$ \\
& $(1.660)$ & $(1.656)$ \\
Observations & 1,009 & 1,155 \\
Number of firms & 233 & 243 \\
Industry FE & YES & YES \\
Year FE & YES & YES \\
Adjusted R-squared & 0.0494 & 0.0426 \\
& & \\
\hline
\end{tabular}

Ha: $\beta 3$ (CFO Internal) $\neq \beta 3$ (CFO External)

$\chi^{2}=0.00$

Panel D: Dependent Variable: Discretionary Accruals; Joint tenure-rank; Hire - CFO

\begin{tabular}{lcc}
\hline VARIABLES & CFO Internal & CFO Extern \\
\hline & & \\
Meet & -0.007 & $-0.042^{* *}$ \\
& $(-0.309)$ & $(-2.163)$ \\
Joint Tenure (rank) & -0.001 & -0.002 \\
& $(-0.142)$ & $(-0.200)$ \\
Meet * Joint Tenure (rank) & 0.026 & $0.040 * *$ \\
& $(1.581)$ & $(2.243)$ \\
Observations & 1,009 & 1,155 \\
Number of firms & 233 & 243 \\
Industry FE & YES & YES \\
Year FE & YES & YES \\
Adjusted R-squared & 0.0509 & 0.0415
\end{tabular}

Ha: $\beta 3$ (CFO Internal) $\neq \beta 3$ (CFO External)

$\chi^{2}=0.44$

Table 7 presents OLS estimations of discretionary accruals on CEO-CFO joint tenure, split into subsamples. Panel A reports the natural logarithm of joint tenure with a subsample split on internally vs. externally hired CEO, Panel B reports tercile ranked joint tenure with a subsample split on internally vs. externally hired CEO, Panel C reports the natural logarithm of joint tenure with a subsample split on internally vs. externally hired CFO, and Panel D reports tercile ranked joint tenure with a subsample split on internally vs. externally hired CFO. Industry and Year fixed effects are included in all columns. Standard errors are clustered by firm. T-statistics are found in the parenthesis. $* * *$, and *** represent two-tailed significance at $10 \%, 5 \%$, and $1 \%$, respectively. Chi-squared test statistics of differences in the coefficients of Meet*Joint Tenure across the two subsamples are also presented. 
Table 8: The Effect of Joint Tenure on Real Earnings Management, Internal vs. External CEO/CFO hires

Panel A: Dependent Variable: Abnormal Discretionary Expenses; Joint tenure-log; Hire - CEO

\begin{tabular}{lcc}
\hline VARIABLES & CEO Internal & CEO External \\
\hline & & \\
Meet & $0.044^{*}$ & 0.032 \\
& $(1.958)$ & $(0.737)$ \\
Joint Tenure $(\log )$ & $-0.033^{* * *}$ & $0.044 * *$ \\
& $(-2.740)$ & $(2.177)$ \\
Meet * Joint Tenure $(\log )$ & -0.025 & -0.034 \\
& $(-1.259)$ & $(-1.542)$ \\
Observations & 1,333 & 736 \\
Number of firms & 276 & 170 \\
Industry FE & YES & YES \\
Year FE & YES & YES \\
Adjusted R-squared & 0.218 & 0.323 \\
\end{tabular}

Ha: $\beta 3$ (CEO Internal) $\neq \beta 3$ (CEO External)

$\chi^{2}=2.34$

Panel B: Dependent Variable: Abnormal Discretionary Expenses; Joint tenure-rank; Hire - CEO

\begin{tabular}{lcc}
\hline VARIABLES & CEO Internal & CEO External \\
\hline \multirow{2}{*}{ Meet } & $0.035^{* *}$ & \\
& $(1.989)$ & 0.015 \\
Joint Tenure (rank) & $-0.025^{* * *}$ & $(0.390)$ \\
& $(-2.875)$ & $(1.980)$ \\
Meet $*$ Joint Tenure (rank) & -0.022 & -0.021 \\
& $(-1.319)$ & $(-0.977)$ \\
Observations & 1,333 & 736 \\
Number of firms & 276 & 170 \\
Industry FE & YES & YES \\
Year FE & YES & YES \\
Adjusted R-squared & 0.219 & 0.320
\end{tabular}

Ha: $\beta 3$ (CEO Internal) $\neq \beta 3$ (CEO External)

$\chi^{2}=1.02$ 
Panel C: Dependent Variable: Abnormal Discretionary Expenses; Joint tenure-log; Hire - CFO

\begin{tabular}{lcc}
\hline VARIABLES & CFO Internal & CFO External \\
\hline \multirow{2}{*}{ Meet } & 0.017 & $0.063^{* *}$ \\
& $(0.552)$ & $(2.377)$ \\
Joint Tenure $(\log )$ & -0.001 & -0.018 \\
& $(-0.082)$ & $(-1.312)$ \\
Meet * Joint Tenure $(\log )$ & -0.022 & $-0.034^{*}$ \\
& $(-0.874)$ & $(-1.755)$ \\
Observations & 937 & 1,132 \\
Number of firms & 216 & 232 \\
Industry FE & YES & YES \\
Year FE & YES & YES \\
Adjusted R-squared & 0.216 & 0.229
\end{tabular}

Ha: $\beta 3$ (CFO Internal) $\neq \beta 3$ (CFO External)
$\chi^{2}=0.04$

Panel D: Dependent Variable: Abnormal Discretionary Expenses; Joint tenure-rank; Hire - CFO

\begin{tabular}{lcc}
\hline VARIABLES & CFO Internal & CFO External \\
\hline Meet & 0.010 & $0.049^{* *}$ \\
& $(0.414)$ & $(2.262)$ \\
Joint Tenure (rank) & -0.002 & $-0.017^{*}$ \\
& $(-0.171)$ & $(-1.649)$ \\
Meet * Joint Tenure (rank) & -0.019 & -0.027 \\
& $(-0.882)$ & $(-1.516)$ \\
Observations & 937 & 1,132 \\
Number of firms & 216 & 232 \\
Industry FE & YES & YES \\
Year FE & YES & YES \\
Adjusted R-squared & 0.215 & 0.230 \\
\end{tabular}

Ha: $\beta 3$ (CFO Internal) $\neq \beta 3$ (CFO External)

$\chi^{2}=0.02$

Table 8 presents OLS estimations of abnormal discretionary expenses on CEO-CFO joint tenure, split into subsamples. Panel A reports the natural logarithm of joint tenure with a subsample split on internally vs. externally hired CEO, Panel B reports tercile ranked joint tenure with a subsample split on internally vs. externally hired CEO, Panel C reports the natural logarithm of joint tenure with a subsample split on internally vs. externally hired CFO, and Panel D reports tercile ranked joint tenure with a subsample split on internally vs. externally hired CFO. Industry and Year fixed effects are included in all columns. Standard errors are clustered by firm. T-statistics are found in the parenthesis. *, **, and $* * *$ represent two-tailed significance at $10 \%, 5 \%$, and $1 \%$, respectively. Chi-squared test statistics of differences in the coefficients of Meet*Joint Tenure across the two subsamples are also presented. 